\title{
THE RISK OF HAVING TO PAY DOUBLE ESTATE AGENT'S COMMISSION
}

\section{$1 \quad$ Introduction}

This note addresses the question whether a seller who mandates more than one estate agent to find a buyer faces the risk of having to pay more than one commission in circumstances where a sale materialises and

(a) it is not entirely clear which estate agent engaged by the seller was the effective cause of the sale; or

(b) the sale agreement signed by the seller stipulates that commission is payable to one of the estate agents but another estate agent was in fact the effective cause of the transaction.

The typical scenario is where the seller gives two estate agents (A and $B$ ) an identical mandate, and each agent subsequently shows the property to the same prospective purchaser. They both explain the property's features, the finance available, their assessment of the market value of the property, and so on. The buyer and seller are keen to buy and sell. One of the following now occurs:

(a) A sale transaction is negotiated between the seller and buyer directly, without any further intervention on the part of any of the two estate agents. The seller's input is minimal, but the facts are such that one cannot determine which estate agent was the effective cause since the value of their efforts towards the sale was more or less identical.

(b) A sale is effected by one of the estate agents (say A), using that agent's standard pre-printed sale agreement containing the usual commission clause whereby the seller agrees to pay commission to agent $A$. On the facts, however, the input of estate agent $B$ was the effective cause of the sale.

Can the seller in either of these situations face the risk of a double commission claim?

\section{Common law}

At common law an estate agent given a mandate to find a buyer for a property is entitled to payment of commission only if it can be established on a balance of probabilities that the estate agent had performed the mandate and that its efforts in finding the buyer were the effective cause of the sale that materialized (Gordon v Slotar 19733 SA 765 (A); Wacks v Record 1955 2 SA 234 (C); and Van Zyl en Seuns (Edms) Bpk v Nel 19753 SA 983 (N)). Putting it differently, at common law an estate agent is not entitled to payment of commission unless it can establish, amongst others, that its 
efforts were the "decisive factor" that triggered the sale (Barnard \& Parry Ltd $v$ Strydom 1946 AD 931) or were "overridingly important" (Aida Real Estate $v$ Lipschitz 19713 SA 871 (W); and Basil Elk Estates (Pty) Ltd v Curzon 1990 2 SA $1(T)$ ), despite the input of the seller and/or that of any other estate agent mandated by the seller.

Whether or not an estate agent is the effective cause a transaction is a question of fact, involving the application of common sense standards (Webranchek $v$ LJ Jacobs \& Co Ltd 19484 SA 671 (A)). Disputes in this regard often arise in practice, particularly so in situations where a seller has engaged more than one estate agent to find a buyer. In such instances the estate agent who introduced the buyer to the property first, or who succeeded in closing the deal, is not necessarily the effective cause of the sale (cf Barnard \& Parry Ltd v Strydom supra; and Howard \& Decker Witkoppen Agencies and Fourways Estates (Pty) Ltd v Desousa 19713 SA $937(\mathrm{~T}))$. All the facts and circumstances must be weighed to determine which estate agent's efforts were the causa causans of the sale (Basil Elk Estates (Pty) Ltd v Curzon supra).

Whether or not a seller can be held bound in principle to pay commission to more than one estate agent arising from the same transaction is not entirely settled in South African law. In Webranchek $v$ LJ Jacobs \& Co Ltd (supra 678) Van den Heever JA raised the possibility that the seller may be liable to pay more than one commission, but the learned judge of appeal found it unnecessary to decide the point finally:

"It was common cause that where a property is listed with several agents and they compete in trying to conclude a sale by the principal to a particular third party, it is not necessarily the agent who first introduces the purchaser who is entitled to remuneration but the agent who is the effective cause of the transaction being completed. ... Situations are conceivable in which it is impossible to distinguish between the efforts of one agent and another in terms of causality or degrees of causation. In such a situation it may well be (it is not necessary to decide the point) that the principal may owe commission to both agents and that he has only himself to blame for his predicament; for he should protect himself against that risk."

English law is equally unclear. It has been said that "the modern judicial tendency" in England is to "pay lip service to the possibility of a double claim, while denying it on the facts of a particular case" (Murdoch The Law of Estate Agency 4ed (2003) 119). Not all English courts, however, favour the possibility of a double commission claim. In AA Dicksen \& Co $v$ O'Leary ((1979) 254 EG 731) Lord Denning expressed the view that

"when a house is in the hands of more than one agent, it cannot be supposed that the vendor is to be made liable for double commission. In the ordinary way commission is payable to the agent who is the first to find a purchaser who enters into a binding contract which both parties accept. If a binding contract is made before another agent has produced 'a person able, ready and willing to purchase' - or before any contract is made with that person the first agent gets commission, the second does not. It is a race as to which agent wins. He wins who first gets the binding contract".

On the other hand, Drake $\mathrm{J}$ in Lordsgate Properties Ltd $v$ Balcombe ([1985] 1 EGLR 20), held that there is no good reason in law why a seller may not be liable to two agents in respect of the same transaction if both 
were instrumental in causing the sale. The learned judge expressed himself as follows:

"But it appears to me that there is no good reason in law why a vendor may not be liable to two agents in respect of the same transaction - provided either (a) both parties were instrumental in effectively causing the sale; or (b) the different contracts entitle each of the agents to commission for different reasons.

It will no doubt be very unusual for a vendor to find himself liable to two agents on the basis that each has been an effective cause in bringing about the sale, without the chain of causation on the side of one agent being broken by the acts of the other. But I can see no reason at all why this unusual situation may not occur ..."

The approach that an estate agent may be entitled to commission on the basis of being "an" (as opposed to "the") effective cause also received the cursory attention of the Court of Appeal in Brian Cooper \& Co v Fairview Estates (Investments) Ltd ([1987] 1 EGLR 18), where Woolf LJ commented as follows on a submission that an implied term should be added to a contract that the estate agent would be entitled to commission if it was an effective cause:

"It is only necessary for me to add that Mr Chadwick submitted that, nowadays, when a term is to be implied the appropriate term to imply is not that set out in the passage from Bowstead which I have quoted but an implied term that the agent is 'an', not 'the', effective cause of the letting. Mr Chadwick may be right as to this in the case of some commission agreements, but I am not satisfied that he is right as to all. It could also create problems where there are two or more effective causes, each of which could be the subject of a claim for commission."

More recently the Queen's Bench Division, Commercial Court (Harding Maughan Hambly Ltd v Compagnie Européenne de Courtage D'Assurances ([2000] 1 All ER (Comm) 225) had the following to say (Rix J):

"Many of the leading cases in this area of the law concern the position of estate agents, and $\mathrm{I}$ am anxious to say nothing in this case to render uncertain what may be established in that context. I note that in two recent cases in the court of appeal the rule is stated in terms of the effective cause: see John D Wood \& Co v. Dantata [1987] 2 EGLR 23, Chasen Ryder \& Co v. Hedges [1993] 08 EG 119. On the other hand, in earlier years the court of appeal spoke in terms of an effective cause: see Millar v. Radford (1903) TLR 575 at 576 and Nightingale v. Parsons [1914] 2 KB 621 at 626, applied by Branson J in McNeil v. Law Union \& Rock Insurance Company Ltd (1925) 23 LL L Rep 314.

I can well see that where the choice faced is essentially between two rival claimants for the same commission, then the court may have to determine which of them is the effective cause: because to say that both were, would or might well lead to the result that the principal would have to pay both agents a full commission. Even so, that may have to be the result, upon the wording of particular contracts, see Lordsgate Properties Ltd v. Balcombe [1985] 1 EGLR 20."

Is it really possible at common law for a seller to be exposed to a double commission claim if it is impossible to distinguish between the efforts of two estate agents and to determine which of them was the effective cause of the transaction? Before answering the question it is necessary to examine more closely in what situations the issue will arise. Although Van Heerden JA in 
Webranchek's case referred to "degrees of causation" courts do not in commission cases place a mathematical value on the input of the respective parties. Adjudicators analyse the facts and take a common sense approach as to whose efforts were the effective cause or decisive factor. However, for present purposes it is useful to illustrate different scenarios expressing by way of percentages the value or importance of the parties' efforts towards the transaction. An estate agent is clearly the effective cause of a sale transaction if its efforts collectively contributed $51 \%$ to the sale. However, $51 \%$ is not necessarily the minimum to be obtained to qualify as the effective cause. A person can be the effective cause of a transaction even if his or her efforts contributed less than $51 \%$ but were relatively speaking more than that of others who also made inputs. Take the case where a seller's input is valued at $40 \%$ and each estate agent's at $30 \%$. In this scenario the seller's efforts are the effective cause relative to that of the two estate agents and no question of commission or double commission would arise. Conversely, where the seller's efforts are valued at $30 \%$, that of estate agent $A$ at $45 \%$ and that of estate agent $B$ at $25 \%$, estate agent $A$ is the effective cause relative to the other parties and it will be entitled to payment of commission. The difficulty, however, comes when the seller's input is say $20 \%$ and that of each estate agent $40 \%$. Is the seller now liable for payment of two commissions despite the fact that neither estate agent's efforts were the decisive factor?

On the one hand it can be argued that an estate agent who claims commission and who cannot persuade a court that its efforts, and not that of another estate agent, were the effective cause of a transaction, cannot succeed in its claim since it has not discharged the onus of proving its case on a balance of probabilities. On the other hand it can be said that if the plaintiff succeeds in persuading a Court that its efforts were as effective as those of another estate agent, it is entitled to commission since the law does not require an estate agent to prove that it was the sole cause of the transaction. Should the other estate agent subsequently institute a claim, a similar decision will be made and the seller will therefore be held liable to pay two commissions in respect of the same transaction.

It is easy to find arguments supporting the first approach. An estate agent who cannot persuade a court that its efforts were the effective cause of a transaction, cannot succeed in a claim for commission. It is not sufficient to show that the efforts were as important as that of another estate agent, because then the plaintiff has not proved on a balance of probabilities that it was the effective cause - it merely proved that its efforts contributed towards the sale and that such efforts, taken with the efforts of another estate agent, triggered the sale. Simply put, two estate agents acting independently of one another cannot both be the effective cause of a sale transaction: one of them is the effective cause, or neither of them is. If their efforts contributed equally to the transaction so that it is impossible to say whom the effective cause was, neither of them is entitled to commission.

This approach obviously offends one's sense of fairness. Why should the seller be allowed to escape liability for payment of commission altogether simply because one cannot determine which estate agent was the effective cause of the transaction, although otherwise it is abundantly clear that the 
seller's own efforts in finding a buyer were minimal and the sale was clearly brought about by the efforts of the estate agents mandated by him? It is no answer to say that the two estate agents should join forces and sue for commission jointly on the basis that their joint efforts were the effective cause and that the seller should therefore pay the commission on the transaction to them jointly. Contractually the two estate agents were not joint contractors acting under a joint mandate - each was given an independent mandate, although the terms were similar (Van Straaten $v$ Harris 19551 SA $73(W))$. Therefore, joint liability does not enter the picture. Apportioning the commission between the two estate agents, taking into account their respective efforts, may well be a desirable solution but currently there is no legal basis on which a court may do so (see Van Jaarsveld "Die Problematiek van Kommissieloon Betaalbaar aan Eiendomsagente" 1974 De Rebus Procuratoriis 161 who argues that a system similar to the Apportionment of Damages Act 34 of 1955 be introduced to provide for the apportionment of commission where several estate agents are involved in a transaction).

A more pragmatic approach is to take the line of reasoning adopted in some English judgments (see above), namely that in order to succeed in a commission claim an estate agent need not establish that it was the effective cause; proving that it was an effective cause is sufficient. On this approach an estate agent would be entitled to payment of commission even if its efforts were not necessarily the "decisive factor" or "overridingly important", as long as they were an effective cause. Accordingly, where more than one estate agent mandated by a seller made an important contribution towards the sale the effective cause requirement is not used to identify which estate agent is entitled to commission to the exclusion of all others, but rather to determine whether a particular estate agent is entitled to payment having regard to the value of its services. In Harding Maughan Hambly Ltd $v$ Compagnie Européenne de Courtage D'Assurances (supra) Rix J referred to the following definition of "an effective cause" in the American Law Institute's Second Restatement of Agency, 1958 (par 448):

"an agent is an 'effective cause' when his efforts have been sufficiently important in achieving a result for the accomplishment of which the principal has promised to pay him, so that it is just that the principal should pay the promised compensation to him."

The judge remarked that although the definition was open to objection

"it seems to me to be none the worse for that. It articulates the thought that the decision on causation is a matter of common sense informed by its context and designed to produce a just result".

Whatever the merits of this approach (further discussion falls outside the scope of the present Note), this is not how South African courts understand and apply the effective cause requirement. While our courts endorse the view that effective cause is a matter of common sense (Webranchek $v$ LJ Jacobs \& Co Ltd supra) they do not interpret this to mean that one simply has to ask whether the estate agent claiming commission has done enough to earn its fee. South African law requires of an estate agent to prove that its efforts were overridingly important or the decisive factor: see the cases cited 
earlier. Thus the concept of an estate agent being "an" effective cause (as defined above) does not readily fit into South African law.

It is simply not fair that a seller should be allowed to escape liability for payment of commission altogether where the efforts of the estate agents mandated by him were the most important contributions towards the sale, and where one cannot in truth say which effort was the decisive factor. It is submitted that in such circumstances it is just and equitable that the seller should pay commission to each of those estate agents. This should be dealt with as an exception to the rule that in order to earn commission an estate agent must prove that its efforts were the effective cause.

It needs to be said that in practice situations will seldom arise where it would in fact be totally impossible to distinguish between the efforts of two or more estate agents and not arrive at a view as to whose inputs were overridingly important. A seller would therefore rarely face a situation where he incurs liability, based on common law, to pay commission to two estate agents mandated to find a buyer. A double commission claim is more likely to arise where the sale agreement signed by the seller contains a commission clause stipulating that commission is payable to estate agent $A$, but the efforts of estate agent B (also mandated by the seller) were in fact the effective cause of the sale. This is discussed next.

\section{Double commission claims arising from a commission clause in a sale agreement}

In practice standard pre-printed sale agreement documents used by estate agents invariably contain a commission clause to the effect that the seller (being the mandatory) agrees to pay a specified commission to a particular estate agent on the occurrence of a certain event. The estate agent in question would normally be the estate agent who attended to the formal sale agreement and whose standard document is being used for that purpose (the "closing agent"). The clause is usually drafted as a stipulation alteri, entitling the closing agent to enforce the terms of the clause on acceptance of the benefit stipulated in its favour (Baker $v$ Afrikaanse Nasionale Maatskappy 19513 SA 371 (A) 376H; Minnaar v Jugdeow 19641 SA 770 (D); Tony Morgan Estates v Pinto 19824 SA 171 (W); Pace Real Estate (Pty) Ltd v Wilson 1983 3 SA 753 (W); and Vesta Estate Agency v Schlom 19911 SA 593 (C)).

Where a seller mandates two or more estate agents to find a buyer a situation often arises in practice where the closing agent was not the effective cause of the sale, but the estate agent who was the effective agent succeeds in claims commission from the seller (see, eg, Munitz v Steer's Trust Co (Pty) Ltd 19932 SA 369 (C)). For present purposes the question is whether the closing agent is then also entitled to payment of commission based on the wording of the commission clause in the sale agreement. If payment can be enforced it would mean that the seller would be paying double commission.

The answer depends on whether or not the effective clause requirement has been excluded by the wording of the commission clause. If it has been 
excluded the seller would have to pay commission to the estate agent who was the effective cause, and commission to the closing agent based on the wording of the commission clause (Hanz Huizeman (Pty) Ltd t/a De Huizemark v Audrey Trezise (unreported case no 19091/82 (W)). If it has not been excluded the seller would incur no liability towards the closing agent (Lieb NNO v I Kuper \& Co 19823 SA 708 (T)), unless the situation discussed earlier arises namely where it is impossible to distinguish between the efforts of the two agents.

Whether or not the effective cause requirement is excluded by agreement depends on the terms of the agreement. It has been held (Lieb NNO $v$ I Kuper \& Co supra) that clear wording is required before a court would interpret a commission clause in a manner whereby the estate agent in question need not prove that its efforts were the effective cause. This is also the approach in England (Brian Cooper \& Co $v$ Fairview Estates (Investments) Ltd supra 18; Midgeley Estates Ltd v Hand [1952] 2 QB 432, 435-6; Countrywide North Ltd v GWM Developments Ltd and Raceview Ltd [2007] CSOH 60; The County Homesearch Company (Thames and Chilterns) Ltd v Cowham [2008] EWCA Civ 26; Foxtons Ltd v Pelkey Bicknell [2008] EWCA Civ 419).

\section{$4 \quad$ Mitigating the risk of double commission}

A seller wishing to avoid the risk of having to pay more than one commission totally, can best do so by not appointing more than one estate agent. However, the position is more challenging where the seller wishes to mandate two or more estate agents. In such instances the risk of double commission can be mitigated to some extent by contractually agreeing with each estate agent that should it appear to be impossible to determine which estate agent was the effective cause of the sale, no commission would be paid or a pro rata share would be paid to each. Additionally, when presented with a sale agreement to sign, the seller should take care to ensure that the commission clause is not worded to the effect that commission is payable to the closing agent even if its efforts were not the effective cause of the sale. The seller may furthermore insist on the inclusion of an indemnity clause in the sale agreement whereby the closing agent agrees to indemnify the seller should it emerge that another estate agent has been in fact the effective cause of the sale.

The effectiveness of these precautionary measures must be seen in context. Useful as they may be, the measures provide no guarantee that a seller who mandated more than one estate agent would not end up in unpleasant commission litigation or that the risk of payment of two commissions is eliminated altogether. In practice, unless payment of commission to the closing agent is queried or challenged soon after the sale of the property, the seller would have no reason to withhold the commission and the closing agent would be paid in good faith, usually upon registration of transfer of the property. Provided the claim has not yet prescribed, one of the other estate agents mandated by the seller may at any time thereafter institute a commission claim on the basis that it was the effective cause of the sale. If the court upholds the claim, the seller would end up having paid 
two commissions unless he succeeds in claiming a refund from the closing agent (whether contractually or on the basis of unjustified enrichment). However, claiming a refund may turn out to be easier said than done, particularly so if the closing agent has in the meantime gone out of business.

Where a seller has appointed two or more estate agents to find a buyer, arguably the best way to avoid commission disputes is not to sell to a buyer who has had dealings with more than one of the seller's estate agents unless the entitlement to commission has been cleared and settled. In this respect it must be kept in mind that there is no legal duty on an estate agent to acquaint the seller with all the various people to whom he has shown the seller's property (Doyle v Gibbon 1919 TPD 220; and Van Zyl \& Seuns (Edms) Bpk $v$ Nel supra 986). Accordingly, if a seller has given an estate agent a mandate to sell and the seller eventually sells privately or through another estate agent, it is the seller's duty to make enquiries whether the buyer had also been in contact with other estate agents relating to the property. Once the facts have been established and the efforts of the various estate agents evaluated, the seller can take a view on how to proceed. Often the estate agents agree to each accept a pro rata share of the commission in full and final settlement. Where negotiations on this basis fail the seller may well decide not to sell to the buyer at all or, alternatively, to proceed with the sale but without paying any commission until ordered to do so by a court.

\section{The estate agents' code of conduct}

In South Africa the activities of estate agents are regulated, amongst others, by a code of conduct framed and published by the Estate Agency Affairs Board and approved by the Minister of Trade and Industry, acting under the powers conferred on them by section 8(b) of the Estate Agency Affairs Act 112 of 1976. The main purpose of the code is to enhance the protection of consumers in their dealings with estate agents. All estate agents are obliged to adhere to the provisions of the code, failing which they face disciplinary action as set out in the Act. If found guilty of a contravention of the code, an estate agent may be reprimanded or fined up to R25 000, or the estate agent's fidelity fund certificate may be withdrawn, resulting in the estate agent's expulsion from the industry (s 30(3)). If a fine has been imposed the Board or a disciplinary committee may order that up to $80 \%$ of the fine be applied towards the payment of compensation to any person who suffered pecuniary loss as a result of the conduct of the estate agent in question (s 30(7)).

There are two clauses contained in the estate agents code of conduct that have a direct bearing on the risk of double commission, namely clauses 2.2 and 8.3.

\section{Clause 2.2}

The clause reads as follows:

"In terms of estate agents' general duty to members of the public and other persons or bodies, an estate agent - 
2.2 shall protect the interests of his client at all times to the best of his ability, with due regard to the interests of all other parties concerned."

In terms of clause 1 of the code of conduct "client" is defined to mean "a person who has given an estate agent a mandate, provided that should an estate agent have conflicting mandates in respect of a particular immovable property, the person whose mandate has first been accepted by the estate agent is regarded as the client".

As stated earlier, at common law an estate agent mandated to sell a property is under no legal obligation to acquaint the seller with all the various people introduced to the property - it is the seller's duty to make the necessary enquiries. In practice, however, sellers are seldom aware of their legal duties in this regard and they mostly sign the sale agreement presented to them by the closing agent without making any enquiries about the purchaser's involvement with other estate agents. Clause 2.2 of the code of conduct is intended, amongst others, to address this issue. Where a double commission dispute arises and it transpires that the seller had in good faith sold to someone not knowing that the buyer also had had dealings with another estate agent concerning the property, the seller may complain that the latter estate agent had failed to protect the interests of its client (the seller) by not informing the seller before conclusion of the sale that it (the estate agent) had negotiations with the purchaser about the property. Although in law this would not be a valid defence for the seller in a commission dispute, the estate agent may expose itself to disciplinary action should it proceed with a commission claim against the seller. In certain instances this may deter the estate agent from continuing with the claim.

The practical effect of clause 2.2 of the code of conduct is that estate agents are encouraged to keep their clients (sellers) informed of the persons to whom the property has been shown. A seller would therefore know whether the buyer to whom he intends selling had been in contact with any of the estate agents mandated by him. This would assist the seller in dealing with a double commission risk.

\section{Clause 8.3}

This clause reads as follows:

"No estate agent shall

$8.1 \quad$...

$8.2 \ldots$

8.3 introduce a prospective purchaser or lessee to any immovable property or to the seller or lessor thereof, if he knows, or has reason to believe, that such person has already been introduced to such property or the seller or lessor thereof by another estate agent and that there is a likelihood that his client may have to pay commission to such other, or to more than one, estate agent should the sale or lease be concluded through his intervention: Provided that the aforegoing shall not apply if the estate agent has informed his client of such likelihood and obtained his written consent to introduce such party to the property or the seller or lessor thereof."

The purpose of this clause is to avoid a double commission dispute where the seller had appointed more than one estate agent to find a buyer. The 
Estate Agency Affairs Board has published a detailed commentary on the practical application and implementation of the code of conduct (Professional Ethics for Estate Agents (1993)) and in terms of this clause 8.3 requires the following conduct of an estate agent:

1 An estate agent $(A)$ who introduces a prospective purchaser to a property must ask the latter whether or not he has seen the property through another estate agent. If the answer is no and the estate agent has no reason to believe otherwise, the estate agent may introduce the purchaser to the property. If a sale follows, the estate agent should for its own protection record in the sale agreement that the purchaser has not been introduced to the property by another estate agent.

2 If the buyer has seen the property with another estate agent (B), estate agent $A$ may still introduce the prospective buyer and show him the property. Estate agent A may not, however, bring about a sale entitling it to payment of commission, unless:

(a) it (or the buyer) has given a suitable indemnity against payment of double commission by the seller, and this has been accepted by the seller; or

(b) a commission split with estate agent $B$ has been negotiated; or

(c) estate agent $A$ has assessed the likelihood of a double commission dispute and arrived at a decision whether or not such a dispute is likely. If a commission dispute is likely, estate agent A must disclose this to the seller and obtain his written consent to proceed with negotiations. On the other hand, if estate agent A considers that there is no likelihood of a double commission dispute, it may proceed to introduce the intending purchaser to the property, having asked him whether he would object to the inclusion of a clause stating that estate agent $A$ is the effective cause of the sale. If the buyer objects, estate agent $A$ must reconsider its position and reassess the likelihood of a double commission dispute.

3 If a double commission dispute is likely, but the result contemplated in (a), (b) or (c) above cannot be achieved, estate agent A must abandon negotiations with that prospective purchaser in respect of the property in question, and not make any claim against the seller for payment of commission should the buyer eventually buy the property through estate agent $\mathrm{B}$.

\section{Conclusion}

The legal position is quite clear: depending on the circumstances a seller who has given more than one estate agent a mandate to find a buyer runs the risk of ultimately having to pay commission to more than one agent. This can to some extent be avoided if estate agents closely follow the guidelines laid down by the Estate Agency Affairs Board in its commentary on clause 8.3 of the code of conduct. In practice many estate agents have, as a result of the provisions of clause 8.3, included a standard indemnity clause in their pre-printed documents whereby the closing agent indemnifies the seller against payment of double commission. The effect is that should an estate 
agent other than the closing agent succeed in establishing that its efforts were the effective cause of the sale, the closing agent will refund the seller the amount of the commission paid to the other estate agent. In this manner the seller is to some extent shielded from the risk of having to pay double commission where more than one estate agent was given a mandate to market the property.

Ultimately, however, the best way to avoid the risk of double commission where more than one estate agent has been mandated to find a buyer is to refrain from selling to a person who has been in contact with more than one of the seller's estate agents until the entitlement to commission has been settled.

Henk Delport

Nelson Mandela Metropolitan University, Port Elizabeth 